\title{
Forage yield and quality of simple and complex grass- legumes mixtures under Mediterranean conditions
}

\author{
Teresa Carita*, Nuno Simões, João Paulo Carneiro, José Moreira e Ana Sofia Bagulho \\ National Institute for Agricultural and Veterinary Research (INIAV, I.P.), Estrada de Gil Vaz, Ap. 6, 7351-901 Elvas, Portugal
}

\section{A B S T R A C T}

\begin{abstract}
In the experiments conducted in 2013/2014 at the National Institute for Agricultural and Veterinary Research (INIAV) experimental station in Elvas - Portugal, the agronomic and forage quality traits of various species (Triticale (X Triticosecale wittmack), Oat (Avena sativa L.), Grasspea (Lathyrus sativus L.), Red vetchling (Lathyrus cicera L.). Hairy vetch (Vicia villosa, Roth), Common vetch (Vicia sativa L.) and Fiel pea (Pisum sativum L.)) in pure stands as well as in mixtures were evaluated. The objective was to identify interesting species or fodder mixture able to produce early interesting biomass, both in quantity and quality, for the periods when there is scarcity of pasture. A randomized complete block design with three replications was used in the experiment. The studied parameters were: dry matter yield, crude protein content, neutral detergent fiber content (NDF) and in vitro digestibility. Analysis of variance revealed highly significant differences $(P<0.05)$ among treatments for all agronomic and forage quality parameters. Lowest dry matter production was recorded in the combination on red vetchling in the first cut $\left(133 \mathrm{~kg} \mathrm{ha}^{-1}\right)$ and with grasspea in the second cut (1266 kg ha-1), but these treatments are characterized by the highest values of protein contents (16-23\%), the highest digestibility (66-81\%) and the lowest NDF content (24-39\%).
\end{abstract}

Keywords: Dry Mediterranean climate; Fodder mixtures; Forages species

\section{INTRODUCTION}

During the past three decades, the livestock sector is growing due to the global expansion in production and consumption of animal products (FAO, 2016). The cattle sector production costs are important, mainly as a result of feed costs, which represent more than 50 percent of the total cost (Sulas et al., 2012). This makes necessary to find solutions to provide high quality animal feed using sustainable production methods. The dominating aspect of Mediterranean climate on agriculture is the scarcity in rainfall and the erratic distribution along the year, showing a coincidence of drought and high temperatures during the summer season. Furthermore, it is also expected that in winter, temperature increase in the Mediterranean region, +1 to $+2^{\circ} \mathrm{C}$ based in the majority of models (Dumont et al, 2011). It is believed these climate changes will affect plant growth and development along with crop yield, Increased inter-annual variability of rainfall and temperature may be another significant aspect of climate change, and this is of high ecological relevance. For this region a slight reduction of precipitation ranging between 0 an $10 \%$ in winter and 10 and 20\% in summer is predicted (Leliévre et al., 2010). Thus, herbage fodder mixtures suitable to grow in these conditions and with high nutritional value in late winter/early spring (time of greatest need of fodder) should be found. Forage nutritional value depends on many factors and it has a direct effect on forage value, animal performance, and, ultimately on farm profits (Ball et al., 2001). The most important factors affecting the forage nutritional value are forage species and growth stage in the moment of harvest. Among the factors affecting forage quality, the objective of this study was to select species and fodder mixtures for high dry matter content and for high quality potential (crude protein, digestibility and NDF).

\section{MATERIALS AND METHODS}

The experiment was conducted during 2013/2014 at the National Institute for Agrarian and Veterinarian Research (INIAV) experimental station in Elvas, Portugal $\left(38^{\circ} 53^{\prime} \mathrm{N}\right.$, $7^{\circ} 08^{\prime} \mathrm{W}, 220 \mathrm{~m}$ above sea level), under vertic-calcaricchromic Cambisol soil. Portugal is mainly characterized

\footnotetext{
*Corresponding author:

Teresa Carita, National Institute for Agricultural and Veterinary Research (INIAV, I.P.). Phone: 00351268637759, Mobile: 351 964442687,

E-mail: teresa.carita@iniav.pt

Received: 14 February 2016;

Revised: 19 March 2016;

Accepted: 22 March 2016;

Published Online: 29 April 2016
} 
by Mediterranean climate (warm to hot dry summers and mild to cool wet winter; rainfall in this area has a strongly seasonal pattern). Two winter cereals (Triticale (X Triticosecale wittmack), Oat (Avena sativa L.)) and five legumes (Grasspea (Lathyrus sativus L.), Red vetchling (Latbyrus cicera L.). Hairy vetch (Vicia villosa Roth), Common vetch (Vicia sativa L.), Field pea (Pisum sativum L.)) in pure stands as well as is mixtures were evaluated (Table 1). INIAV-Portugal cultivars were chosen to this study.

A randomized complete block design with three replications was used in the experiment. Each plot consisted of 8 rows with $5 \mathrm{~m}$ length. The space between rows was $25 \mathrm{~cm}$. Sowing was done by hand on November 14 ${ }^{\text {th }}, 2013$. Dry matter yield was evaluated by two sequential cuts throughout the growing season. The plant samples were taken from a randomly selected $0,438 \mathrm{~m}^{2}(1,75 \mathrm{~m}$ x 0,25m) area of each plot. The first harvest time was based on (i) the occurrence of flowering (at 10\% of plants) in legumes pure stands and (ii) at appearance of the first node (Zadoks

\begin{tabular}{|c|c|c|}
\hline \multicolumn{2}{|c|}{ Treatments } & \multirow{2}{*}{$\begin{array}{c}\text { Seed density } \\
160 \mathrm{~kg} \mathrm{ha}^{-1}\end{array}$} \\
\hline $\mathrm{T} 1$ & Triticale (Fronteira) & \\
\hline T2 & Oat (S Eulália) & $130 \mathrm{~kg} \mathrm{ha}^{-1}$ \\
\hline T3 & Grasspea A & $160 \mathrm{~kg} \mathrm{ha}^{-1}$ \\
\hline T4 & Grasspea B & $80 \mathrm{~kg} \mathrm{ha}^{-1}$ \\
\hline T5 & $\begin{array}{l}\text { Red vetchling A (Grão da } \\
\text { Gramicha) }\end{array}$ & $130 \mathrm{~kg} \mathrm{ha}^{-1}$ \\
\hline T6 & $\begin{array}{l}\text { Red vetchling B (Grão da } \\
\text { Gramicha) }\end{array}$ & $65 \mathrm{~kg} \mathrm{ha}^{-1}$ \\
\hline $\mathrm{T} 7$ & Hairy Vetch A (Amoreiras) & $30 \mathrm{~kg} \mathrm{ha}^{-1}$ \\
\hline T8 & Hairy Vetch B (Amoreiras) & $15 \mathrm{~kg} \mathrm{ha}^{-1}$ \\
\hline T9 & Field pea A (Pixel) & $160 \mathrm{~kg} \mathrm{ha}^{-1}$ \\
\hline T10 & Common vetch (Graveza) & $80 \mathrm{~kg} \mathrm{ha}^{-1}$ \\
\hline T11 & Triticale+Grasspea & $60 \mathrm{~kg} \mathrm{ha}^{-1}+80 \mathrm{~kg} \mathrm{ha}^{-1}$ \\
\hline $\mathrm{T} 12$ & Triticale+Red vetchling & $60 \mathrm{~kg} \mathrm{ha}^{-1}+65 \mathrm{~kg} \mathrm{ha}^{-1}$ \\
\hline T13 & Triticale+Hairy vetch & $60 \mathrm{~kg} \mathrm{ha}^{-1}+20 \mathrm{~kg} \mathrm{ha}^{-1}$ \\
\hline $\mathrm{T} 14$ & Triticale+Field pea & $60 \mathrm{~kg} \mathrm{ha}^{-1}+80 \mathrm{~kg} \mathrm{ha}^{-1}$ \\
\hline T15 & Triticale+Common vetch & $60 \mathrm{~kg} \mathrm{ha}^{-1}+50 \mathrm{~kg} \mathrm{ha}^{-1}$ \\
\hline T16 & Oat+Grasspea & $45 \mathrm{~kg} \mathrm{ha}^{-1}+80 \mathrm{~kg} \mathrm{ha}^{-1}$ \\
\hline $\mathrm{T} 17$ & Oat+Red vetchling & $45 \mathrm{~kg} \mathrm{ha}^{-1}+65 \mathrm{~kg} \mathrm{ha}^{-2}$ \\
\hline T18 & Oat+Hairy vetch & $45 \mathrm{~kg} \mathrm{ha}^{-1}+20 \mathrm{~kg} \mathrm{ha}^{-3}$ \\
\hline T19 & Oat+Field pea & $45 \mathrm{~kg} \mathrm{ha}^{-1}+80 \mathrm{~kg} \mathrm{ha}^{-4}$ \\
\hline T20 & Oat+Common vetch & $45 \mathrm{~kg} \mathrm{ha}^{-1}+50 \mathrm{~kg} \mathrm{ha}^{-4}$ \\
\hline T21 & $\begin{array}{l}\text { Triticale+Grasspea+Hairy } \\
\text { vetch }\end{array}$ & $60 \mathrm{~kg} \mathrm{ha}^{-1}+60 \mathrm{~kg} \mathrm{ha}^{-1}+10 \mathrm{~kg} \mathrm{ha}^{-1}$ \\
\hline T22 & $\begin{array}{l}\text { Triticale+Grasspea+Field } \\
\text { pea }\end{array}$ & $60 \mathrm{~kg} \mathrm{ha}^{-1}+60 \mathrm{~kg} \mathrm{ha}^{-1}+60 \mathrm{~kg} \mathrm{ha}^{-1}$ \\
\hline T23 & $\begin{array}{l}\text { Triticale+Red } \\
\text { vetchling+Hairy vetch }\end{array}$ & $60 \mathrm{~kg} \mathrm{ha}^{-1}+45 \mathrm{~kg} \mathrm{ha}^{-1}+10 \mathrm{~kg} \mathrm{ha}^{-1}$ \\
\hline T24 & $\begin{array}{l}\text { Triticale+Red } \\
\text { vetchling+Field pea }\end{array}$ & $60 \mathrm{~kg} \mathrm{ha}^{-1}+45 \mathrm{~kg} \mathrm{ha}^{-1}+60 \mathrm{~kg} \mathrm{ha}^{-1}$ \\
\hline T25 & $\begin{array}{l}\text { Oat+Grasspea+Hairy } \\
\text { vetch }\end{array}$ & $45 \mathrm{~kg} \mathrm{ha}^{-1}+60 \mathrm{~kg} \mathrm{ha}^{-1}+10 \mathrm{~kg} \mathrm{ha}^{-1}$ \\
\hline T26 & $\begin{array}{l}\text { Oat+Red vetchling+Hairy } \\
\text { vetch }\end{array}$ & $45 \mathrm{~kg} \mathrm{ha}^{-1}+45 \mathrm{~kg} \mathrm{ha}^{-1}+10 \mathrm{~kg} \mathrm{ha}^{-2}$ \\
\hline
\end{tabular}

stage 31) (Zadoks et al., 1974) for cereal pure stands and for all mixtures. Plots were clipped for a second time, in the end of April at cereal grain watery ripe - GS71 according to Zadoks's scale - Zadoks et al., 1974). Plant sub-samples were taken from each plot, dried in a forced-air oven at $50^{\circ} \mathrm{C}$ and weighted to obtain dry matter yield. The crude protein content was measured by Kjeldahl method (ISO 5983-1: 2005) and the conventional factor of $\mathrm{N} x 6.25$ was used. The NDF content (neutral detergent fiber) was measured according to ISO 16472.2005 with lower modifications. The in vitro digestibility was estimated according to the determination in vitro of the dry matter digestibility of samples that was performed by the two stage pepsin-cellulase enzymatic method (Jones and Hayward, 1975). Data were analyzed using SPSS version 17.0 software (SPSS Inc., Chicago, IL). The differences between means were separated by Tukey multiple range test $(\mathrm{P} \leq 0.05)$.

\section{RESULTS AND DISCUSSION}

The annual precipitation for this agricultural year was $775 \mathrm{~mm}$, and the mean monthly temperature varied between $8.9^{\circ} \mathrm{C}$ in December and $24.9^{\circ} \mathrm{C}$ in July. After sowing date, a very dry period of 1.5 months (rainfall below $15 \mathrm{~mm}$ per month) was reported. Therefore, emergence was low and in every plot the distribution of plants was irregular.

Significant differences were observed among treatments in dry matter yield, crude protein content, neutral detergent fiber content and digestibility, indicating considerable genetic and agronomic variability for these parameters.

\section{Dry matter yield}

The dry matter yield recorded at two different growth stages of pure stands and forage mixtures is presented in Table 2.

Average dry matter (DM) content increased with delaying cutting date from first to second cutting date. DM varied from $581 \mathrm{~kg} \mathrm{ha}^{-1}$ to $3327 \mathrm{~kg} \mathrm{ha}^{-1}$. From Table 2 it can be seen that, at cut I, the highest dry matter was obtained by the common vetch (T10) that was not significantly different from T8 compared to almost all the other treatments. For for both cuts and unlike another studies (Ansar et al., 2010; Alami et al., 2015), no significant differences were recorded between binary and ternary mixtures. This occurrence is not in agreement with the conclusions of Papadopoulos et al. (2012), who reported increased forage yields when mixture complexity increased. Likewise, Picasso et al. (2011) asserted that choosing a single well-adapted species for maximum productivity could not be the best alternative over the long term, and that high levels of species diversity should be 
Table 2: Dry matter yield (DM) of 26 treatments in both cutting times

\begin{tabular}{|c|c|c|c|c|c|}
\hline \multirow[t]{2}{*}{ Treatments } & \multicolumn{2}{|c|}{ DM (kg ha $\left.{ }^{-1}\right)$} & \multirow[t]{2}{*}{ Treatments } & \multicolumn{2}{|c|}{ DM (kg ha-1) } \\
\hline & Cut I & Cut II & & Cut I & Cut II \\
\hline T1 & $658 b c$ & $3520 a b c$ & $\mathrm{~T} 14$ & $661 b c$ & $3276 a b c$ \\
\hline T2 & $434 \mathrm{bc}$ & $6430 a$ & $\mathrm{~T} 15$ & $409 b c$ & 4849abc \\
\hline T3 & $594 b c$ & $1266 c$ & $\mathrm{~T} 16$ & $517 \mathrm{bc}$ & $5366 a b$ \\
\hline T4 & $351 b c$ & $1374 \mathrm{c}$ & $\mathrm{T} 17$ & $571 b c$ & $3760 a b c$ \\
\hline T5 & $133 c$ & $1332 c$ & $\mathrm{~T} 18$ & $530 \mathrm{bc}$ & $4617 a b c$ \\
\hline T6 & $223 c$ & $2055 b c$ & T19 & $574 b c$ & $2721 a b c$ \\
\hline T7 & $447 \mathrm{bc}$ & $1949 b c$ & T20 & $501 b c$ & $3904 a b c$ \\
\hline T8 & $1153 a b$ & - & T21 & $374 b c$ & 4777abc \\
\hline T9 & $918 b c$ & $2795 a b c$ & T22 & $650 \mathrm{bc}$ & $3045 a b c$ \\
\hline $\mathrm{T} 10$ & $2014 a$ & - & T23 & $463 b c$ & 2644abc \\
\hline $\mathrm{T} 11$ & $594 \mathrm{bc}$ & 2808abc & T24 & $497 \mathrm{bc}$ & $3458 a b c$ \\
\hline $\mathrm{T} 12$ & $336,0 \mathrm{bc}$ & $2091 b c$ & $\mathrm{~T} 25$ & $382 b c$ & 4971abc \\
\hline T13 & $632 b c$ & $2727 a b c$ & T26 & $501 b c$ & 3922abc \\
\hline Mean $_{(\mathrm{T} 1-\mathrm{T} 26)}$ & 581 & 3327 & Mean $_{(\text {(T1-Т26) }}$ & 581 & 3327 \\
\hline $\begin{array}{l}\text { Level of } \\
\text { significance }\end{array}$ & *** & $* \star *$ & $\begin{array}{l}\text { Level of } \\
\text { significance }\end{array}$ & $* \star *$ & $* * *$ \\
\hline
\end{tabular}

Means followed by the same letter are not significantly different at $\mathrm{P}<0.05$

Table 3: Crude protein (CP) content of 26 treatments in first cut time

\begin{tabular}{|c|c|c|c|}
\hline \multirow[t]{2}{*}{ Treatments } & CP (\%) & \multirow[t]{2}{*}{ Treatments } & \multirow{2}{*}{$\begin{array}{c}\text { CP (\%) } \\
\text { Cut I }\end{array}$} \\
\hline & Cut I & & \\
\hline $\mathrm{T} 1$ & 12.3ef & $\mathrm{T} 14$ & $12.60 \mathrm{ef}$ \\
\hline T2 & $12.10 f$ & T15 & 16.93abcdef \\
\hline T3 & $22.51 \mathrm{ab}$ & T16 & 16.87abcdef \\
\hline T4 & $23.00 a$ & $\mathrm{~T} 17$ & $16.30 \mathrm{cdef}$ \\
\hline T5 & 20.33abcd & T18 & $14.60 \mathrm{def}$ \\
\hline T6 & $21.80 a b c$ & T19 & $12.60 \mathrm{ef}$ \\
\hline T7 & 17.70abcdef & T20 & 15.17def \\
\hline T8 & 17.80abcdef & T21 & 17.70abcdef \\
\hline T9 & 14.70def & T22 & 15.67cdef \\
\hline T10 & 17.10abcdef & T23 & 18.37abcde \\
\hline T11 & $16.43 \mathrm{bcdef}$ & T24 & $16.47 \mathrm{bcdef}$ \\
\hline T12 & 18.23abcdef & T25 & $13.88 \mathrm{ef}$ \\
\hline T13 & $16.53 b c d e f$ & T26 & $16.19 \mathrm{cdef}$ \\
\hline $\operatorname{Mean}_{(\mathrm{T} 1-\mathrm{T} 26)}$ & 16.69 & Mean $_{(\mathrm{T} 1-\mathrm{T} 26)}$ & 16.69 \\
\hline $\begin{array}{l}\text { Level of } \\
\text { significance }\end{array}$ & $* * *$ & $\begin{array}{l}\text { Level of } \\
\text { significance }\end{array}$ & $* * *$ \\
\hline
\end{tabular}

Means followed by the same letter (s) are not significantly different at $\mathrm{P}<0.05$.

included in the design of productive and ecologically sound agricultural systems. At the present study, in pure stand, there were significant differences among some treatments and between cutting time (Cut I and Cut II). The highest dry matter yield was obtained in oat (Cut II (cut at the end of spring without winter use) $\left.-6430 \mathrm{~kg} \mathrm{ha}^{-1}\right)$, which has typically a highest-yielding forage, and in common vetch (Cut I - $2014 \mathrm{~kg} \mathrm{ha}^{-1}$ ). Common vetch and hairy vetch are late flowering species, when compared with the other legumes. So, the total accumulated dry matters until occurrence of flowering (Cut I) were bigger. On the other hand the lowest dry matter yield was observed in red vetchling (Cut I - $133 \mathrm{~kg} \mathrm{ha}^{-1}$ ) and grasspea (Cut II $\left.1266 \mathrm{~kg} \mathrm{ha}^{-1}\right)$.

\section{Crude protein content}

Forage protein content is often considered a good index of quality. The crude protein content of different treatments at different growth stages are shown in Tables 3 and 4 . The average crude protein contents declined by increasing crops maturity (Mean Cut I: 16.7\%; Mean Cut II: 13.0\%). Crude protein content was always lower for triticale and oat pure stand and for binary mixture cereal + field pea (T1, T2 and T14) compared with Lathyrus pure stand treatments (T3, T4 and T5). One of main qualities of these forages crops (grasspea and red vetchling) consist of its high protein content (Polignano, 2007). The results of this study, show higher protein content than observed by Foster et al. (2014) and similar than Van Saun (2016) results. This is because, there were selected for this study various forage legumes varieties which generally produce high quality forage.

\section{Digestibility}

Concerning to the forage quality, digestible energy (digestibility) is the most common limiting factor. However, there are times when protein and minerals are the nutrients that limit animal performance, especially in grazing situations when supplementation is impractical. (Ball et al, 2001). Maturity stage at harvest is the most important factor that determines forage quality of a given species, including digestibility. According to Ball et al (2001), digestibility declines by $1 / 3$ to $1 / 2$ percentage units per day until it reaches a level below 50\% (it may happen after the blooming period). In the first cut, digestibility values ranged in this study from $61.8 \%$ (T8-Hairy vetch) to $84.7 \%$ (T2-Oat) (Table 5). The beginning of flowering for vetch species (date of first cut) happened late in relation to all the other species in this study. Hence, this is related to the lowest values of their digestibility, which are significantly lower than those obtained from other treatments.

As it is known, digestibility varies greatly. This parameter decreases as the plant matures. So, as expected, the value for this characteristic is lower in the second cut (average variation between cuts: $62 \%$ (Cut II) - 78\% (Cut I). The lowest value in the second cut was obtained in T1-Triticale $(49.3 \%)$ and the highest in the T9- field pea $(70.7 \%)$.

\section{Neutral detergent fiber (NDF) content}

Legumes usually have less neutral fibre content (NDF) than grasses which promote a higher intake of the former family by animals. Neutral Detergent Fibre content is important because they reflect the amount of forage consumed by the animal. The higher the NDF percent, the lower the dry matter intake. Favourable average NDF were recorded in 
Table 4: Crude protein (CP) content of 26 treatments in second cut tim

\begin{tabular}{|c|c|c|c|}
\hline \multirow[t]{2}{*}{ Treatments } & \multirow{2}{*}{$\begin{array}{c}\text { CP (\%) } \\
\text { Cut II }\end{array}$} & \multirow[t]{2}{*}{ Treatments } & \multirow{2}{*}{$\begin{array}{c}\text { CP (\%) } \\
\text { Cut II }\end{array}$} \\
\hline & & & \\
\hline$\overline{\mathrm{T} 1}$ & $8.50 d$ & T14 & $9.82 \mathrm{bcd}$ \\
\hline T2 & $7.95 d$ & T15 & $12.43 a b c d$ \\
\hline T3 & $17.78 \mathrm{a}$ & T16 & 13.17abcd \\
\hline T4 & $17.93 a$ & $\mathrm{~T} 17$ & $10.43 \mathrm{bcd}$ \\
\hline T5 & $16.93 a$ & T18 & 13.90abcd \\
\hline T6 & $15.60 \mathrm{abc}$ & T19 & $9.34 \mathrm{~cd}$ \\
\hline T7 & 16.17ab & T20 & $14.97 a b c$ \\
\hline T8 & - & T21 & 13.37abcd \\
\hline T9 & $12.30 \mathrm{abcd}$ & T22 & 12.77abcd \\
\hline T10 & - & T23 & $12.53 \mathrm{abcd}$ \\
\hline T11 & $14.20 \mathrm{abcd}$ & T24 & $12.00 \mathrm{abcd}$ \\
\hline T12 & $11.75 \mathrm{abcd}$ & T25 & 12.60abcd \\
\hline T13 & 14.10abcd & T26 & $11.66 \mathrm{abcd}$ \\
\hline Mean $_{(\mathrm{T} 1-\mathrm{T} 26)}$ & 13.01 & Mean $_{(\mathrm{T} 1-\mathrm{T} 26)}$ & 13.01 \\
\hline Level of significance & $* * *$ & Level of significance & $* * *$ \\
\hline
\end{tabular}

Means followed by the same letter (s) are not significantly different at $\mathrm{P}<0.05$ treatments with grasspea (T3, T4) and red vetchling (T5, T6) on pure stand in both cutting times (Fig. 1). On the other hand, the highest average NDF content (62.63\%) was determined in triticale harvested at cereal grain watery ripe - GS71 of Zadoks's scale (Zadoks et al., 1974). These results were comparable to values reported by Lithourgidis et al. (2006) and Kocer and Albayrak (2012). Neutral Detergent Fibre contents of all treatments increased by delaying harvesting; this was as expected because of the maturation progress of each species.

\section{CONCLUSIONS}

This study showed that for combined positive productivity and quality it is essential include legumes on fodder mixtures, especially those with higher contribution to increase the protein content and forage digestibility, as well as to decrease NDF content, such as, the genus Lathyrus.

Table 5: Digestibility (Digest) content of 26 treatments in two cutting times

\begin{tabular}{|c|c|c|c|c|c|}
\hline \multirow[t]{2}{*}{ Treatments } & \multicolumn{2}{|c|}{ Digest (\%) } & \multirow[t]{2}{*}{ Treatments } & \multicolumn{2}{|c|}{ Digest (\%) } \\
\hline & 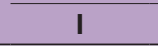 & II & & $\mathbf{I}$ & II \\
\hline T1 & $81,83 a b$ & $49,25 c$ & $\mathrm{~T} 14$ & $79,87 a b c d$ & $56,20 \mathrm{bc}$ \\
\hline T2 & $84,70 a$ & $59,30 a b c$ & $\mathrm{~T} 15$ & $79,73 a b c d$ & $56,20 \mathrm{bc}$ \\
\hline T3 & $75,03 \mathrm{~cd}$ & $66,73 a b$ & $\mathrm{~T} 16$ & $80,93 a b c$ & $64,57 a b$ \\
\hline T4 & $76,47 \mathrm{bcd}$ & $66,70 \mathrm{ab}$ & $\mathrm{T} 17$ & $81,07 a b$ & $63,03 a b$ \\
\hline T5 & $80,37 a b c d$ & $66,00 \mathrm{ab}$ & T18 & $77,12 \mathrm{bcd}$ & $63,17 a b$ \\
\hline T6 & $81,77 a b$ & $66,20 a b$ & T19 & $81,93 a b$ & $63,07 a b$ \\
\hline T7 & $68,00 \mathrm{e}$ & $60,57 a b c$ & T20 & $81,50 a b$ & $67,13 a b$ \\
\hline T8 & $61,83 f$ & - & T21 & $76,83 \mathrm{bcd}$ & $59,37 a b c$ \\
\hline T9 & $80,43 a b c d$ & $70,67 a$ & T22 & $80,13 a b c d$ & $62,97 a b$ \\
\hline T10 & $68,00 e$ & - & T23 & $76,23 \mathrm{bcd}$ & $61,40 a b$ \\
\hline T11 & $81,33 a b$ & $58,67 \mathrm{bc}$ & T24 & $79,80 \mathrm{abcd}$ & $61,75 a b$ \\
\hline T12 & $80,20 \mathrm{abcd}$ & $58,05 b c$ & T25 & $80,70 a b c$ & $60,37 a b c$ \\
\hline T13 & $74,50 \mathrm{~d}$ & $59,45 a b c$ & T26 & $78,37 \mathrm{bcd}$ & $61,30 a b$ \\
\hline Mean $_{(\mathrm{T} 1-\mathrm{T} 26)}$ & 78,03 & 61,76 & $\operatorname{Mean}_{(\mathrm{T} 1-\mathrm{T} 26)}$ & 78,03 & 61,76 \\
\hline Level of significance & $* \star *$ & $* * *$ & Level of significance & $* * *$ & $* * *$ \\
\hline
\end{tabular}

Means followed by the same letter (s) are not significantly different at $\mathrm{P}<0.05$
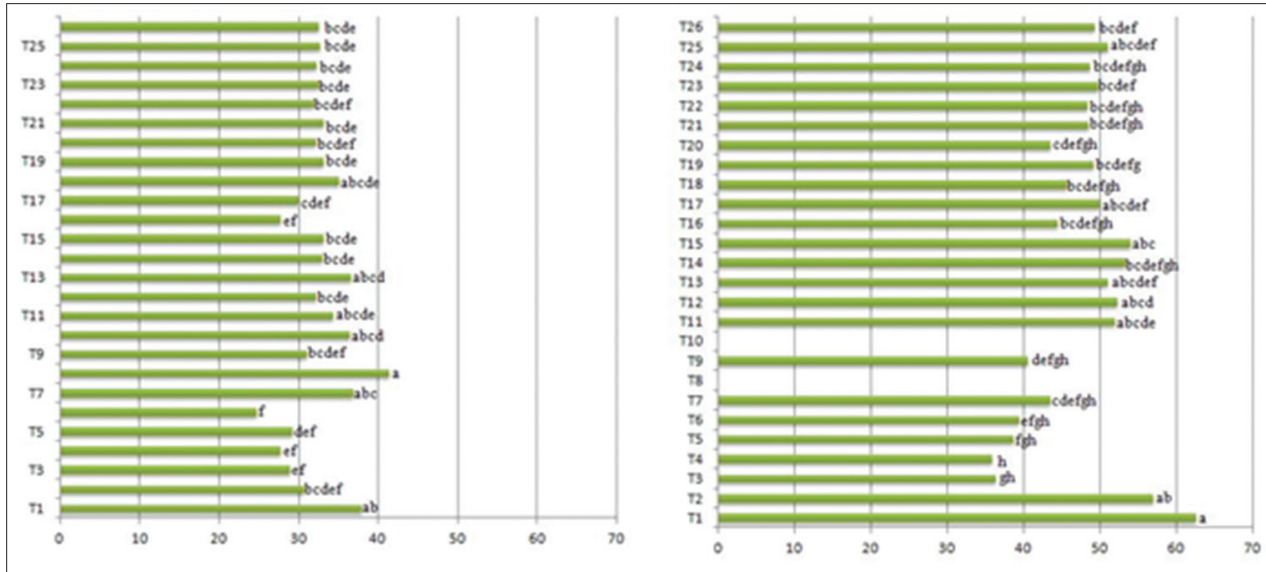

Fig 1. Neutral detergent fibre values of the 26 treatments in cut I (left) and in Cut II (right) cutting times (means followed by the same letter(s) are not significantly different at $\mathrm{P}<0.05$ according to Tukey analysis). 
It has also been shown that increasing the complexity of the mixture had slightly different effects on the forage production and forage quality.

\section{REFERENCES}

Alami, I., L. Pecetti, A. Souihka and P. Annicchiarico. 2015. Optimizing species and variety choice in legume-cereal mixtures as forage crops in a dry Mediterranean region. $31^{\text {st }}$ International EUCARPIA Symposium Section Fodder Crops and Amenity Grasses: Breeding in a World of Scarcity. Ghent - Belgium, 13-17 September.

Ansar, M., Z. Ahmed, M. Malik, M. Nadeem, A. Majeed and B. Rischkowsky. 2010. Forage yield and quality potential of winter cereal-vetch mixtures under rainfed conditions. Emirates J. Food Agric. 22(1): 25-36.

Ball, D., M. Collins, G. Lacefield, N. Martin, D. Mertens, K. Olson, D. Putnam, D. Undersander and M. Wolf. 2001. Understanding Forage Quality. American Farm Bureau Federation Publication 1-01, Park Ridge, IL. P. 20.

Crespo, D. 2010. $\mathrm{m}$ tempos de crise qual o papel das pastagens e forragens no desenvolvimento da agricultura. Trifolia. Newsletter da Sociedade Portuguesa de Pastagens e Forragens. Vol. 1. p. 1-3.

Dumont, B., D. Andueza, V. Niderkorn, A. Lüscher, C. Porqueddu and C. Picon-Cochard. 2011. Effects of climate change on forage quality of grasslands and their use by grazing animals. "An Integration of Mitigation and Adaptation Options for Sustainable Livestock Production under Climate Change ANIMALCHANGE." (Project Supported by the EU - FP 7 (FP7/ 2007-2013). Available from: http://www.animalchange.eu. [Last consulted on 2016 Oct 01].

FAO. 2016. The Global Livestock Sector - A Growth Engine. Available from: ftp://ftp.fao.org/docrep/fao/010/ai554e/ai554e00.pdf. [Last consulted on 2016 Dec 01].

Foster, A., C. Vera, S. Malhi and F. Clarke. 2014. Forage yield of simple and complex grass-legume mixtures under two management strategies. Can. J. Plant Sci. 94(1): 41-50.

Kocer, A. and S. Albayrak. 2012. Determination of forage yield and quality of pea (Pisum sativum L.) mixtures with oat and barley. Turk. J. Field Crops. 17(1): 96-99.

Leliévre F., A. Sala and F. Volaire. 2010. Climate change at the temperate-Mediterranean interface in southern France and impacts on grassland production. Options Méditerr. A-9: 187-192.

ISO, 16472. 2005. Animal Feeding Stuffs - DETERMINATION of Amylase-Treated Neutral Detergent Fibre Content (NDF). International Standardization Organization, p. 16.

ISO, 5983-1. 2005. Animal Feeding Stuffs - Determination of Nitrogen Content and Calculation of Crude Protein Content - Part 1: Kjeldahl Method. International Standardization Organization, p. 10.

Jones, D. and M. Hayward. 1975. The effect of pepsin pretreatment of herbage on the prediction of dry matter digestibility from solubility in fungal cellulose solutions. J. Sci. Food Agric. 26: 711-718.

Papadopoulos, Y., M. McElroy, S. Filmore, K. McRae, J. Duyinsveld. and A. Fredeen. 2012. Sward complexity and grass species composition affect performance of grass-white clover pasture mixtures. Can. J. Plant Sci. 92: 1199-1205.

Picasso, V., E. Charles Brummer, M. Liebman, P.M. Dixon and B. J. Wilsey. 2011. Diverse perennial crop mixtures sustain higher productivity over time based on ecological complementarity. Renewable Agriculture and Food Systems. 1-11.

Sulas, C., P. Rudaa, M. Salis, A. S. Atzori, F. Correddu, A. Cannas and A. M. Carroni. 2012. Legume-cereal mixtures in Sardinia. Options Méditerr. Ser A Mediterr. Semin. 102: 489-492.

Van Saun, R. 2016. What is forage quality and how does it effect a feeding program? Available from: http://www.extension.psu. edu/animals/camelids/nutrition/what-is-forage-quality-andhow-does-it-effect-a-feeding-program. [Last consulted on 2016 Jan 13].

Zadoks, J. C., T. T. Chang and C. F. Konzak. 1974. A decimal code for the growth stages of cereals. Weed Res. 14: 415-421. 